\title{
Perilaku Aliran Stratified Ditinjau dari Karakteristik Visual dan Tebal Film Cairan pada Pipa Horizontal
}

\author{
I. D. Arirohman ${ }^{1, *}$, A. Z. Hudaya ${ }^{1,2}$, Deendarlianto ${ }^{1,3}$, Indarto ${ }^{1,3}$ \\ 1Departemen Teknik Mesin dan Industri, Fakultas Teknik, Universitas Gadjah Mada Jl. Grafika No. 2 Yogyakarta 55281 \\ 2Jurusan Teknik Mesin, Fakultas Teknik, Universitas Muria Kudus Gondangmanis, Bae, Kudus 59324 \\ 3Pusat Studi Energi, Universitas Gadjah Mada Sekip K-1A Kampus UGM, Yogyakarta 55281 \\ *e-mail: ilhamd.ari@gmail.com
}

\begin{abstract}
The characteristics of the liquid film of the air-water stratified co-current two-phase flow were investigated experimentally. The inner diameter and the pipe length were $26 \mathrm{~mm}$ and $9.5 \mathrm{~m}$ respectively. The superficial water and air velocities ranged $(0,01-0,1) \mathrm{m} / \mathrm{s}$ and $(4-20) \mathrm{m} / \mathrm{s}$, respectively. The liquid film thickness data were obtained by using the developed parallel wire sensors. The results indicated that the averaged liquid film thickeness decreases with the increase of the superficial gas velocity. Next, the wave velocity increases with the increase both of gas and liquid superficial velocities
\end{abstract}

Keywords: Stratified flow, parallel wire, liquid film thickness, borizontal flow.

\begin{abstract}
Abstrak
Perilaku aliran stratified searah horizontal diteliti secara eksperimental dengan menggunakan metode parallel wire dan visual. Eksperimen dilakukan pada pipa akrilik berdiameter $26 \mathrm{~mm}$ dan panjang 9,5 m. Beberapa sub pola aliran stratified yang telah dilaporkan oleh peneliti-peneliti sebelumnya dapat teramati dengan melakukan variasi kecepatan superfisial udara $\left(J_{\mathrm{G}}\right)$ dari 4 $20 \mathrm{~m} / \mathrm{s}$ dan kecepatan superfisial air $\left(\mathrm{J}_{\mathrm{L}}\right)$ dari $0,01-0,1 \mathrm{~m} / \mathrm{s}$. Ketebalan film cairan diukur dengan menggunakan sensor parallel wire, sementara kecepatan gelombang dihitung berdasarkan waktu delay yang diperoleh dari teknik cross correlation. Dari hasil penelitian disimpulkan bahwa ketebalan rerata film cairan menurun seiring meningkatnya $\mathrm{J}_{\mathrm{G}}$, sementara kecepatan gelombang secara umum meningkat dengan meningkatnya $\mathrm{J}_{\mathrm{G}}$ dan $\mathrm{J}_{\mathrm{L}}$.
\end{abstract}

Kata kunci: Stratified, parallel wire, ketebalan film cairan, kecepatan superfisial, kecepatan gelombang

\section{PENDAHULUAN}

Aliran stratified adalah salah satu tipe aliran dua fase yang sering dijumpai dalam industri, misal pada shell-tube heat exchanger, sistem perpipaan minyak, pressurerized water reactor (PWR), dan lainnya. Pada aliran stratified dalam pipa horizontal, kedua fase mengalir secara terpisah. Fase cair mengalir pada bagian bawah, sementara fase gas mengalir pada bagian atas pipa. Aliran stratified adalah jenis aliran yang cukup aman untuk sistem perpipaan karena tidak ada fluktuasi tekanan yang sangat besar yang dapat memicu terjadinya blasting.

Bae dkk. (2017) mengamati karakteristik beberapa sub pola aliran stratified pada saluran kotak dengan lebar $40 \mathrm{~mm}$ dan tinggi $50 \mathrm{~mm}$. Dari hasil penelitiannya disimpulkan bahwa kecepatan gelombang antarmuka (interfacial wave) meningkat seiring meningkatnya $R e_{g}$ dan $R e_{l}$. 
Sementara menurut penelitian yang dilakukan oleh Hudaya dkk. (2016), kecepatan gelombang antarmuka meningkat dengan bertambahnya kecepatan superfisial udara pada sub pola aliran yang sama.

Peneliti-peneliti sebelumnya telah mengembangkan beberapa metode pengukuran untuk aliran stratified, salah satunya adalah metode konduktansi menggunakan sepasang kawat sejajar atau lebih dikenal sebagai metode parallel wire. Metode ini memanfaatkan sifat konduktansi cairan dan kawat. Secara teoretik, nilai resistansi antara dua kawat sejajar akan berubah nilainya sebagai fungsi dari ketebalan film cairan yang membasahi kedua kawat. Dengan mengukur beda tegangan listrik antara kedua kawat, maka ketebalan film cairan pada waktu tertentu dapat diperkirakan. Brown dkk. (1978) menggunakan wire probes berbahan platinum berdiameter 0,06 mm dengan jarak spacing antar kawat $3 \mathrm{~mm}$ untuk mengukur ketebalan film cairan dan mendeteksi gelombang gangguan pada aliran annular downward. Badaruddin dkk. (2016) juga menggunakan metode ini untuk mengidentifikasi aliran counter-current dengan pola aliran stratified, wavy, dan slug pada pipa hotleg akrilik berdiameter $25,4 \mathrm{~mm}$.

Tujuan penelitian ini adalah mempelajari perilaku ketebalan film cairan pada aliran stratified searah horizontal dengan menggunakan metode parallel wire. Parameter kajian meliputi ketebalan film cairan dan kecepatan gelombang.

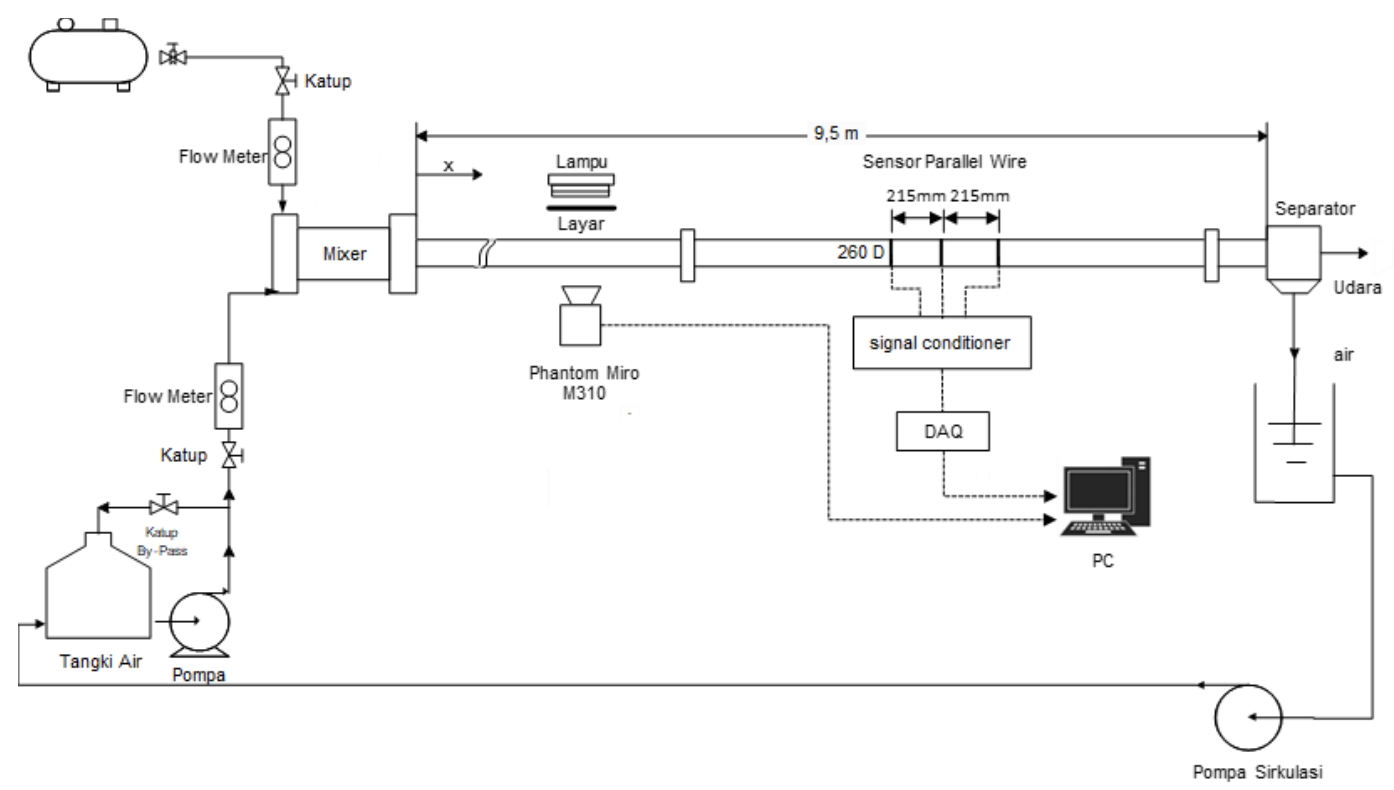

Gambar 1. Skema alat penelitian

\section{METODE PENELITIAN}

Penelitian ini dilakukan di Instalasi Riset Aliran Dua Fase Air-Udara, Laboratorium Mekanika Fluida, Departemen Teknik Mesin dan Industri, Fakultas Teknik, Universitas Gadjah Mada. Eksperimen dilakukan pada kondisi tekanan dan temperatur atmosferik, $1 \mathrm{~atm}$ dan 30 -C. Fluida kerja yang digunakan adalah air kran dan udara. Gambar 1 menunjukkan skema alat penelitian, air dan udara masuk ke pipa melalui mixer. Pengamatan fenomena aliran stratified dilakukan secara visual dan pengukuran kuantitatif dengan menggunakan sensor paraller wire. Pada pipa outlet, fluida air dan udara dipisahkan dengan menggunakan separator. Udara 
dilepaskan ke lingkungan sedangkan air ditampung dalam tangki outlet untuk dialirkan kembali ke tangki inlet.

Sensor parallel wire terdiri dari sepasang kawat sejajar yang terbuat dari tembaga berlapis perak dengan diameter $0,51 \mathrm{~mm}$ dan jarak spacing $5 \mathrm{~mm}$. Ada dua sensor parallel wire yang dipasang pada pipa akrilik transparan berdiameter $26 \mathrm{~mm}$ dan panjang 9,5 $\mathrm{m}$, dengan jarak antar sensor $215 \mathrm{~mm}$. Sensor dihubungkan dengan sebuah rangkaian signal conditioner yang dicatu dengan sumber listrik DC 12 Volt. Sinyal keluaran dari signal conditioner kemudian dikirimkan ke sistem akuisisi data (DAQ). Pada penelitian ini pengambilan data menggunakan sampling rate 500 sampel/s. Gambar 2 dan 3 menunjukkan sistem pengukuran dengan metode parallel wire.

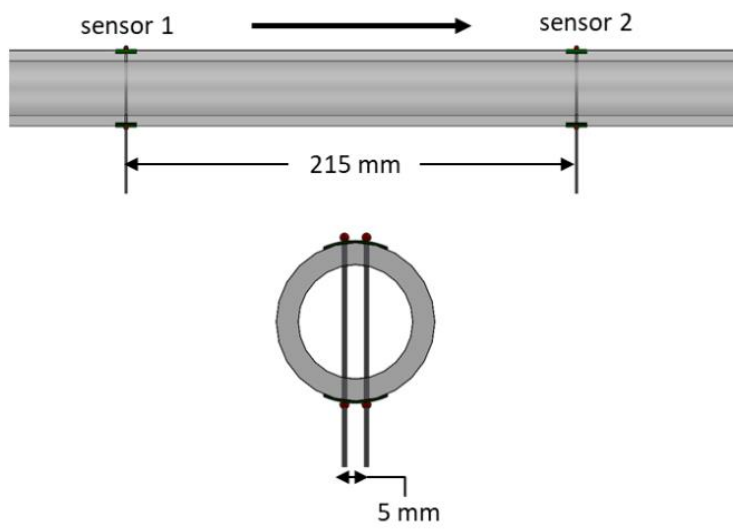

Gambar 2. Mounting sensor parallel wire pada pipa uji

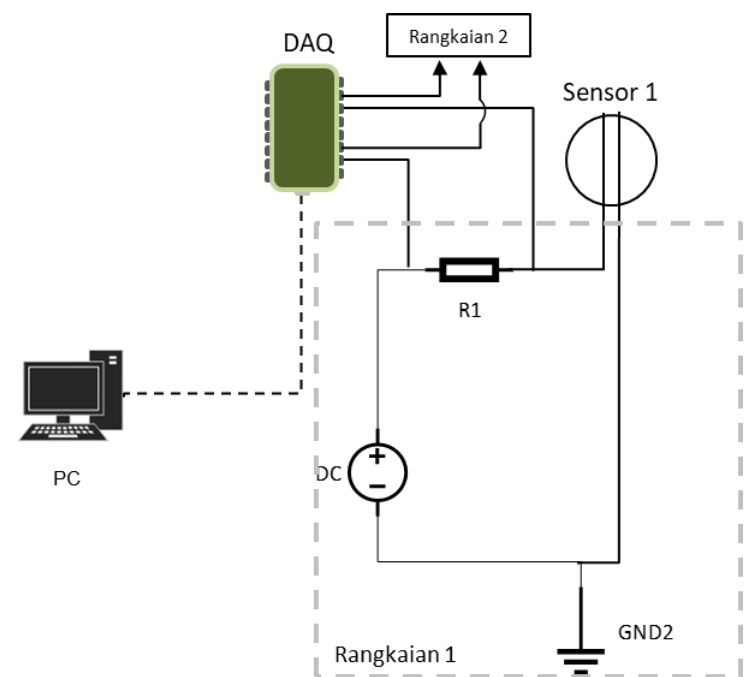

Gambar 3. Skema sistem pengukuran ketebalan film cairan

Kalibrasi sensor dilakukan dengan cara mengukur sinyal keluaran berupa nilai beda tegangan listrik pada ketebalan film cairan tertentu, ketebalan diukur menggunakan mikrometer. Kalibrasi dilakukan pada kondisi statis (tanpa aliran). Kemudian, pengukuran sinyal keluaran dari sensor dilanjutkan dengan menaikkan tebal cairan $1 \mathrm{~mm}$ secara bertahap. 
Eksperimen ini dilakukan dengan mengalirkan air dan udara secara simultan ke dalam pipa akrilik. Kecepatan superfisial air $\left(J_{L}\right)$ divariasikan antara 0,01-0,1 m/s dan kecepatan superfisial udara $\left(J_{G}\right)$ divariasikan antara $4-20 \mathrm{~m} / \mathrm{s}$. Pengambilan data beda tegangan dilakukan pada 72 variasi kecepatan superfisial air dan udara. Untuk mendapatkan visualisasi aliran digunakan kamera highspeed Phantom Miro M310.

Data beda tegangan yang diperoleh dari hasil pengukuran kemudian dikonversi menjadi data ketebalan film cairan menggunakan piecewise Langrange interpolation dengan data kalibrasi sebagai acuannya. Data ketebalan film selanjutnya dianalisis menggunakan teknik cross correlation untuk mendapatkan waktu delay sinyal dari kedua sensor. Informasi waktu delay digunakan untuk menghitung kecepatan gelombang.

\section{HASIL DAN PEMBAHASAN}

Dalam aliran dua fase pada pipa horizontal terdapat beberapa jenis pola aliran yang bergantung pada kecepatan masing-masing fase. Peneliti-peneliti sebelumnya setidaknya telah mengklasifikasi aliran dua fase horizontal menjadi enam pola aliran, yaitu aliran stratified smooth, stratified wavy, plug, slug, annular, dan dispersed bubble (Taitel dkk., 1978). Chen dkk.. (1997) lebih detail lagi membagi aliran stratified wavy menjadi empat sub pola aliran, yaitu aliran 2-D wave, 3D wave, roll wave, dan entrained droplet. Pada penelitian ini, kajian dilakukan untuk mempelajari perilaku ketebalan film cairan dari aliran stratified searah horizontal.

Gambar 4 menunjukkan hasil pengamatan visual dan grafik ketebalan film cairan. Sub pola aliran yang telah disebutkan oleh peneliti-peneliti sebelumnya berhasil teramati dalam penelitian ini. Gambar 4.a mengilustrasikan aliran stratified smooth, yang dicirikan dengan batas antarmuka fase yang relatif datar tanpa adanya gangguan (flate line). Jenis aliran ini terjadi pada kecepatan superfisial udara yang rendah. Dengan meningkatnya kecepatan superfisial udara, gelombang pada batas antarmuka fase mulai muncul akibat adanya interfacial instability, yaitu terjadi ketidakseimbangan antara energi angin yang diumpankan ke batas antarmuka dan viscous dissipation (Andritsos dan Hanratty, 1987).

Gambar 4.b menunjukkan sub pola aliran 2-D wave ditandai dengan adanya gelombanggelombang teratur dengan ukuran yang kecil dan relatif sama pada batas antarmuka. Lebih jauh lagi, penambahan kecepatan superfisial udara meningkatkan ketidakstabilan di batas antarmuka. Pola aliran bergeser menjadi 3-D wave, gelombang-gelombang yang terbentuk tidak teratur baik ukuran dan jarak antar gelombangnya. Menurut Chen dkk. (1997) pada pola aliran ini terjadi wave spreading effect, yaitu ketika fase cair menaiki dinding dalam pipa dan membentuk kurvatur pada batas antarmuka yang dekat dengan dinding pipa. Sub pola aliran 3-D wave ditunjukkan pada Gambar 4.c.

Aliran 3-D wave dapat berkembang menjadi aliran roll wave ketika kecepatan superfisial udara dan/atau air dinaikkan. Aliran ini ditandai dengan adanya gelombang yang menggulung serta beberapa gelembung udara yang terperangkap di sekitarnya. Terjadi lonjakan ketebalan film cairan pada aliran roll wave yang lebih besar daripada aliran 3-D wave. Menurut Hudaya dkk. (2016) pada aliran roll wave, shear stress yang searah aliran meningkat dan menekan cairan sehingga liquid holdup-nya turun, namun karena liquid discharge tetap sama maka akan terjadi lonjakan liquid boldup tiba-tiba pada daerah tertentu di dalam aliran. Gambar 4.d mengilustrasikan sebuah sub pola aliran roll wave.

Lin dan Hanratty (1987) mengusulkan sub pola aliran pseudo-slug. Aliran ini teramati pada daerah transisi antara aliran stratified dan slug. Pada aliran ini terjadi fenomena dimana puncak gelombang mencapai bagian atas pipa dan menyebabkan blockage pada aliran walaupun 
hanya sesaat. Gambar 4.e adalah visualisasi dari sub pola aliran pseudo-slug. Gambar 4.f menunjukkan sub pola aliran entrained droplet. Aliran ini teramati pada kecepatan superfisial udara $>14 \mathrm{~m} / \mathrm{s}$ dan kecepatan superfisial air $>0,02 \mathrm{~m} / \mathrm{s}$. Aliran ini dicirikan dengan adanya droplet cairan yang lepas dari batas antarmuka dan terbawa aliran udara. Ketika kecepatan superfisial udara dinaikkan pola aliran akan bertransisi menjadi aliran annular (Gambar 4.g).

Ketebalan rerata film cairan akan menurun saat $J_{G}$ dinaikkan. Desakan udara terhadap batas antarmuka menyebabkan terjadinya wave spreading effect. Ketebalan rerata film berkurang karena sebagian volume air mulai menyebar dan menaiki dinding di bagian samping. Kondisi ini terus berlangsung hingga keseluruhan bagian dinding pipa terlapisi cairan, pada kondisi ini lapisan film cairan berbentuk seperti cincin dan disebut sebagai aliran annular. Perubahan ketebalan rerata film cairan terhadap $J_{L}$ dan $J_{G}$ ditunjukkan Gambar 5.

Gambar 6.a adalah tipikal grafik dari fungsi cross correlation terhadap shift time. Waktu delay adalah nilai shift time dimana fungsi bernilai maksimum. Gambar 6.b adalah grafik hubungan antara kecepatan gelombang dengan kecepatan superfisial udara dan air. Kecepatan gelombang dihitung dengan membagi jarak antar sensor dengan waktu delay yang sudah diperoleh dengan teknik cross correlation.
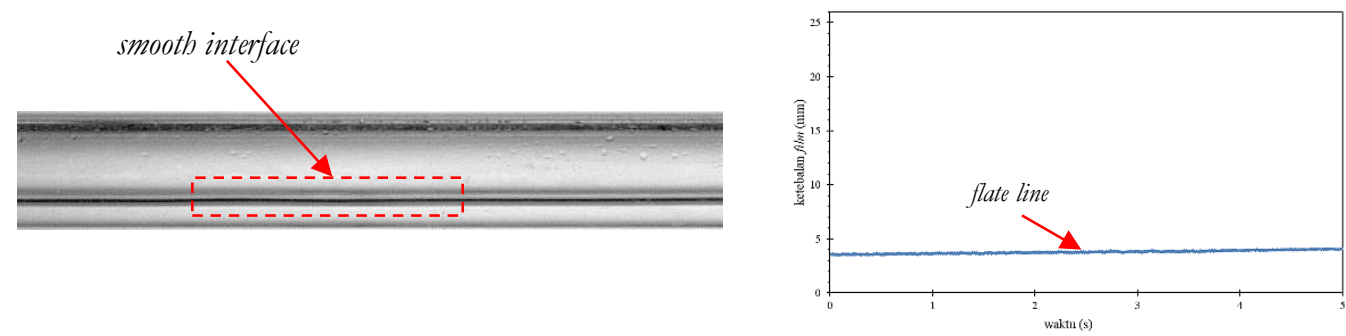

a. Stratified smooth $\left(J_{L}=0,02 \mathrm{~m} / \mathrm{s} ; J_{G}=4 \mathrm{~m} / \mathrm{s}\right)$
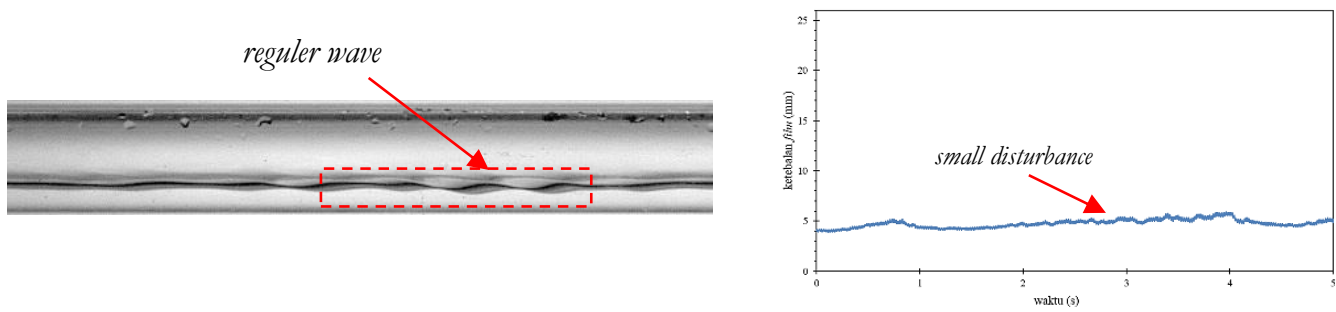

b. 2-D wave $\left(J_{L}=0,03 \mathrm{~m} / \mathrm{s} ; J_{G}=5 \mathrm{~m} / \mathrm{s}\right)$
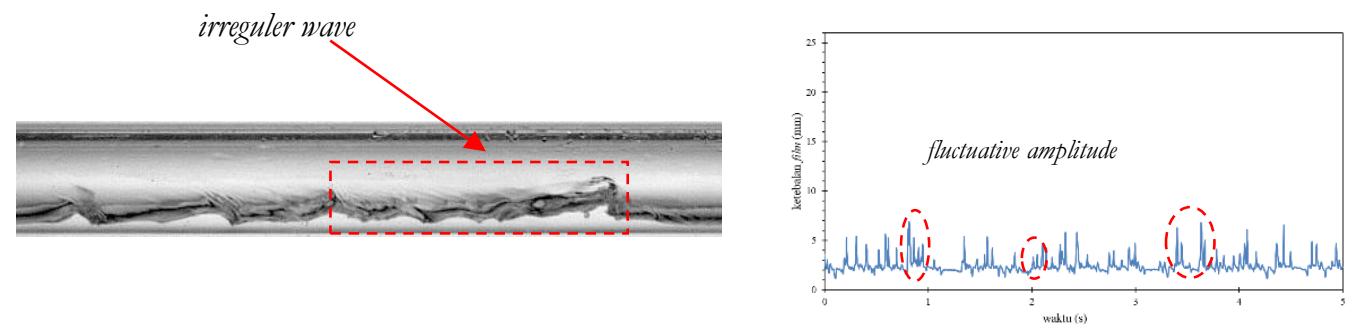

roll wave

c. 3-D wave $\left(J_{L}=0,03 \mathrm{~m} / \mathrm{s} ; J_{G}=9 \mathrm{~m} / \mathrm{s}\right)$ 
I. D. Arirohman dkk. / Journal of Mechanical Design and Testing 1(2), (2019), 86-94
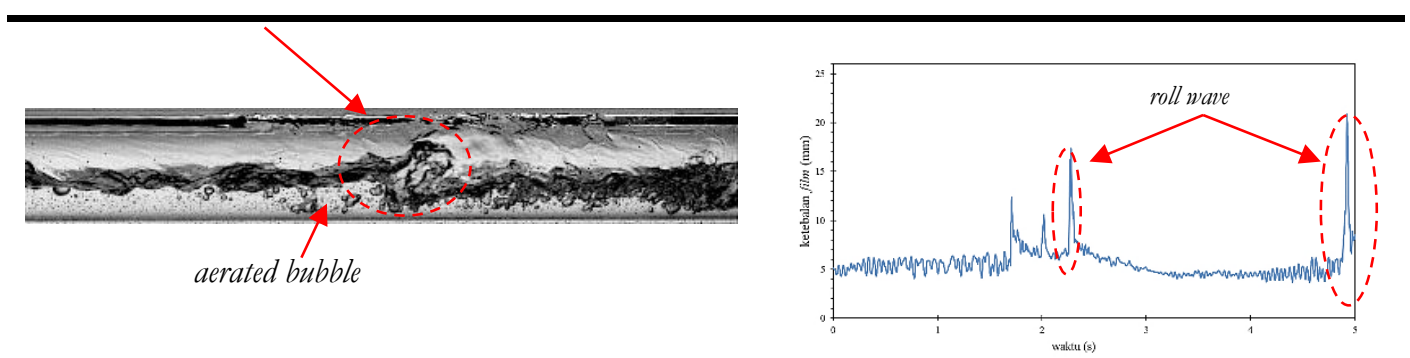

d. Roll wave $\left(J_{L}=0,075 \mathrm{~m} / \mathrm{s} ; J_{G}=5 \mathrm{~m} / \mathrm{s}\right)$
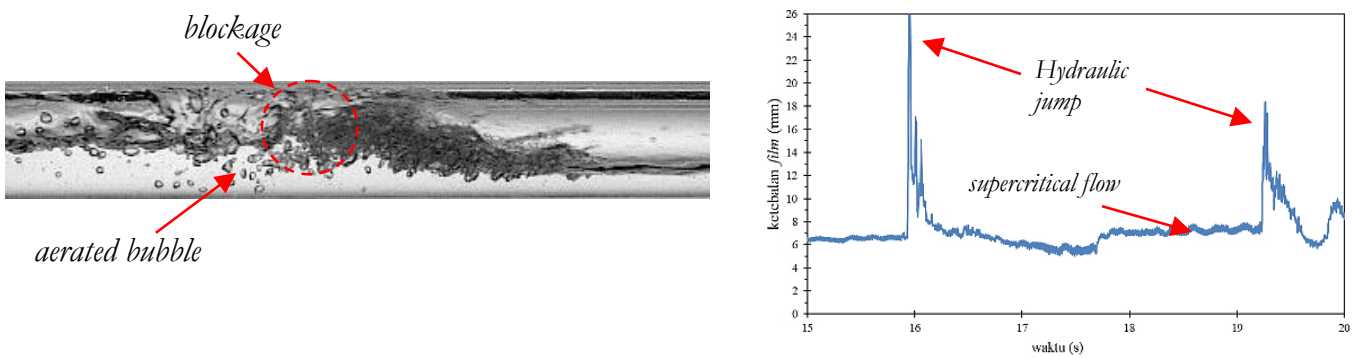

e. Pseudo-Slug $\left(J_{L}=0,1 \mathrm{~m} / \mathrm{s} ; J_{G}=4 \mathrm{~m} / \mathrm{s}\right)$
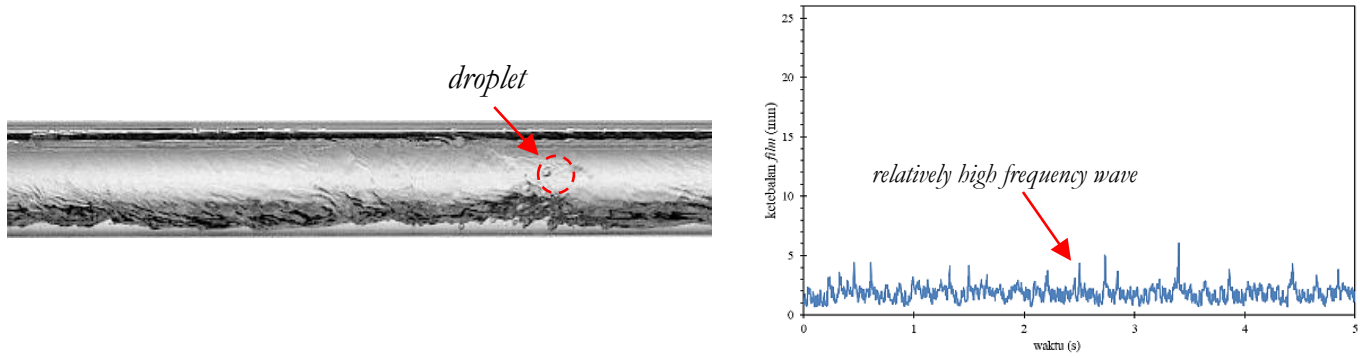

f. Entrained $\operatorname{droplet}\left(J_{L}=0,075 \mathrm{~m} / \mathrm{s} ; J_{G}=14 \mathrm{~m} / \mathrm{s}\right)$
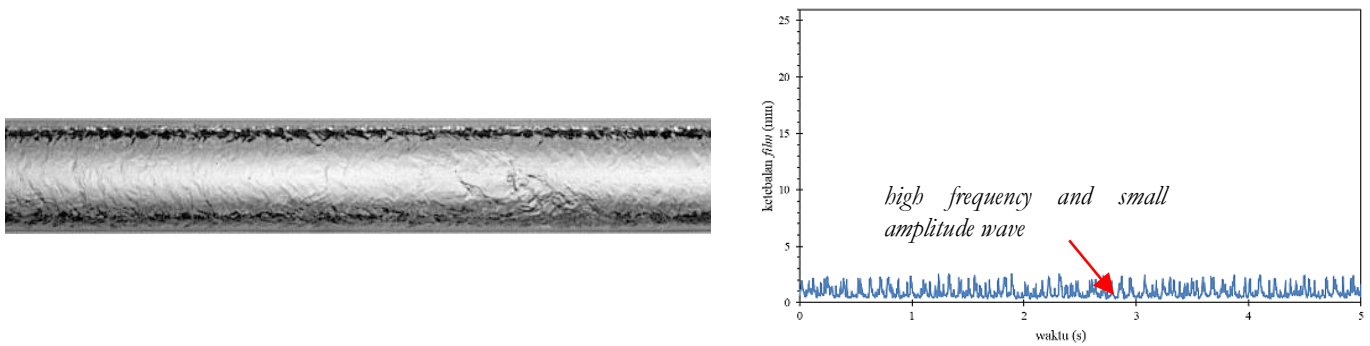

$$
\text { g. Annular }\left(J_{L}=0,075 \mathrm{~m} / \mathrm{s} ; J_{G}=20 \mathrm{~m} / \mathrm{s}\right)
$$

Gambar 4. Visualisasi sub pola aliran dan grafik ketebalan film cairan dalam domain waktu

Dapat dilihat pada grafik bahwa secara umum kecepatan gelombang meningkat seiring dengan meningkatnya kecepatan superfisial air dan udara. Hasil ini sama dengan apa yang telah dilaporkan Bae dkk. (2017) untuk aliran stratified pada saluran kotak $40 \mathrm{~mm} \times 50 \mathrm{~mm}$. Namun ada hasil yang sedikit berbeda yaitu pada $J_{L}=0,075 \mathrm{~m} / \mathrm{s}$ dan $0,1 \mathrm{~m} / \mathrm{s}$ pada $J_{G}=4 \mathrm{~m} / \mathrm{s}$, 
kecenderungan kecepatan gelombang menurun terhadap kenaikan $J_{G}$ hingga nilai $J_{G}=8 \mathrm{~m} / \mathrm{s}$, kemudian kecepatan gelombang meningkat terhadap kenaikan $J_{G}$. Hal ini disebabkan terbentuknya aliran pseudo-slug pada $J_{L}$ yang tinggi dan $J_{G}$ yang rendah. Kecepatan gelombang dapat cukup tinggi karena gas tersumbat sehingga gradien tekanan naik dan memberikan gaya dorong yang cukup besar pada gelombang di depannya (Rahmandhika, 2018).

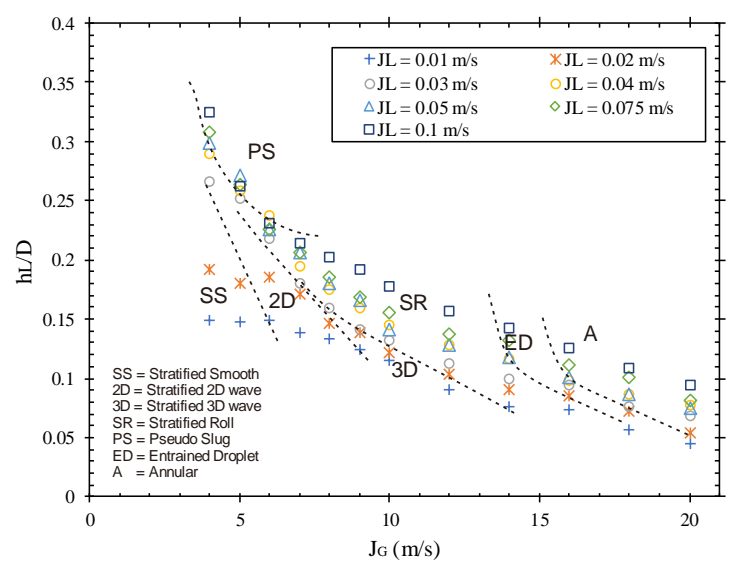

Gambar 5. Perubahan ketebalan rerata film cairan terhadap $J_{L}$ dan $J_{G}$

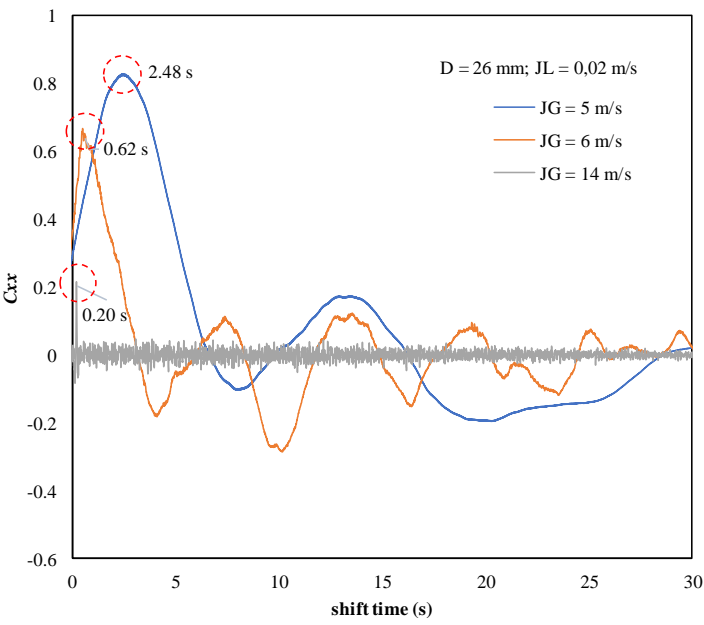

(a) 
I. D. Arirohman dkk. / Journal of Mechanical Design and Testing 1(2), (2019), 86-94

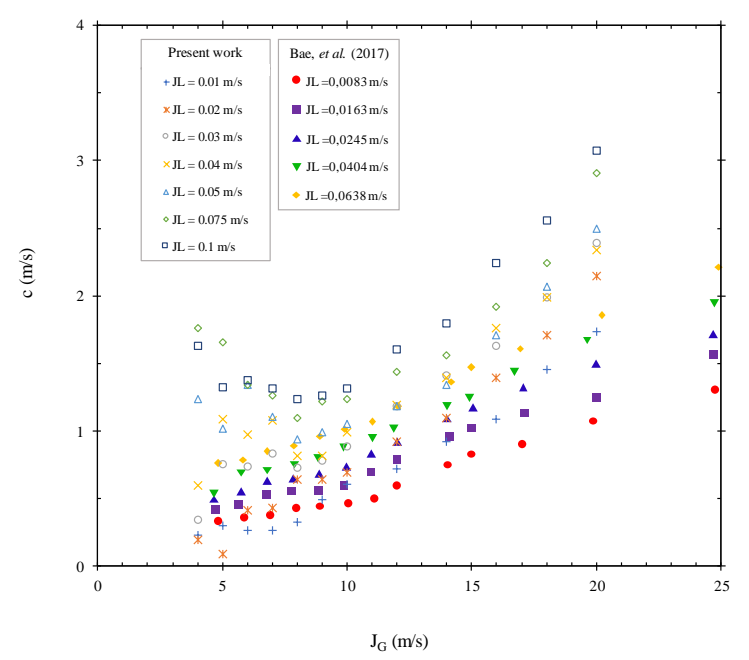

(b)

Gambar 6. (a) Fungsi cross correlation (b) Pengaruh $J_{L}$ dan $J_{G}$ terhadap kecepatan gelombang

\section{KESIMPULAN}

Metode parallel wire dapat digunakan untuk mengukur ketebalan film cairan pada aliran stratified searah horizontal. Ketebalan rerata film cairan menurun seiring meningkatnya kecepatan superfisial udara. Sementara kecepatan gelombang secara umum meningkat dengan meningkatnya kecepatan superfisial udara dan air. Kecepatan gelombang pada aliran pseudo-slug cukup tinggi walaupun nilai $J_{G}$ rendah dikarenakan adanya mekanisme blockage aliran udara. 


\section{DAFTAR PUSTAKA}

Bae, B., Ahn, T., Jeong, J., Kim, K., Yun, B., Characteristics of an Interfacial Wave in a Horizontal Air-Water Stratified Flow, International Journal of Multiphase Flow, Vol. 97 (2017) pp. 197-205.

Hudaya, A.Z., Kuntoro, H.Y., Dinaryanto, O., Deendarlianto, Indarto, Experimental Investigation on the Interfacial Characteristics of Stratified Air-Water Two-Phase Flow in a Horizontal Pipe, AIP Coonference Proceedings 1737 (2016), 040012-1 - 04001210.

Brown, R. C., Andreussi, P., Zanelli, S., The Use of Wire Probes for The Measurement of Liquid Film Thickness in Annular Gas-Liquid Flows, The Canadian of Chemical Engineering, Vol. 36 (1978) pp. 754-757.

Badarudin, A., Arman, M., Interpretasi Hasil Pengukuran Tebal Cairan pada Aliran Dua Fase Udara-Air Berlawanan Arah Menggunakan Metode Parallel-Wire dalam Pipa Kompleks, Prosiding Seminar Nasional XI STTN Yogyakarta, (2016) pp. 369-374.

Taitel, Y., Lee, N., Dukler, A.E., Transient Gas-Liquid Flow in Horizontal Pipes : Modeling The Flow Pattern Transitions, AIChE Journal, Vol. 24, No. 5 (1978) pp. 920-934.

Chen, X.T., Cal, X. D.; Brill, J. P., Gas-Liquid Stratified-Wavy Flow in Horizontal Pipelines, Journal of Energy Resources Technology, Vol. 119 (1997) pp. 209-216.

Andritsos, N., Hanratty, T.J., Interfacial instabilities for horizontal gas-liquid flow in pipelines. International Journal of Multiphase Flow, Vol. 13 (1987) pp. 583-603.

Lin, P.Y., Hanratty, T.J., Effect of Pipe Diameter on Flow Patterns for Air-Water Flow in Horizontal Pipes, International Journal of Multiphase Flow, Vol. 13, No. 4 (1987) pp. 549-563.

Rahmandhika, A, Studi Eksperimental Mengenai Transisi Aliran Stratified ke Slug pada Aliran Dua Fasa Air-Udara dalam Pipa Horizontal, Tesis, Universitas Gadjah Mada, 2018. 